\title{
O sagrado e o profano na poesia de Mário de Andrade
}

\author{
[ The sacred and the profane in the poetry of Mário de Andrade
}

\section{Caion Meneguello Natal ${ }^{\mathrm{x}}$}

Este trabalho conta com auxílio financeiro da Fundação de Amparo à Pesquisa do Estado de São Paulo (Fapesp), na forma de bolsa de pesquisa de pós-doutorado.

\begin{abstract}
RESUMO - $O$ artigo aborda a relação entre sagrado e profano na poesia de Mário de Andrade em princípios da década de I920. São analisados seis poemas: "Noturno", "Jorobabel”, "XXXIII”, "XXXIII (bis) Platão”, “Carnaval carioca" e "Religião". Para tanto, dialogamos com o conceito de "verso harmônico", tal como exposto no manifesto vanguardista "Prefácio interessantíssimo", publicado no livro Pauliceia desvairada (I922). O objetivo é mostrar como o eixo sagrado-profano relaciona-se a dualidades mais gerais presentes nos versos do autor modernista, como vida e escrita, humano e divino, linguagem e realidade, entre outros. • PALAVRAS-CHAVE • Sagrado; profano; poesia;
\end{abstract}

religião. • ABSTRACT - The article discusses the relationship between sacred and profane in the poetry of Mário de Andrade in the early I920s. Six poems are analyzed: "Noturno", "Jorobabel", "XXXIII", "XXXIII (bis) Platão”, "Carnaval carioca" and "Religião". For this, we dialogue with the concept of "harmonic verse", as explained in the avant-garde manifesto "Prefácio interessantíssimo", published in the book Pauliceia desvairada (I922). The goal is to show how the sacred-profane axis relates to more general dualities present in the verses of the modernist author, as life and writing, human and divine, language and reality, among others. $\cdot$ KEYWORDS $\cdot$ Sacred; profane; poetry; religion.

Recebido em II de junho de 2018

Aprovado em II de março de 2019

NATAL, Caion Meneguello. O sagrado e o profano na poesia de Mário de Andrade. Revista do Instituto de Estudos Brasileiros, Brasil, n. 72, p. I62-I83, abr. 2019.

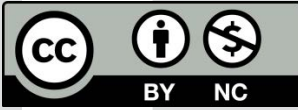

DOI: http://dx.doi.org/Io.II6o6/issn.23I6-9oIX.voi72pI62-I83

I Universidade de São Paulo (USP, São Paulo, SP, Brasil). 
De acordo com Mircea Eliade (I992), práticas religiosas formalizadas, cujos ritos e dogmas concorrem à estruturação de condutas e valores sociais, concebem o sagrado como uma esfera apartada do mundo conhecido. Tal esfera diz respeito à morada do Criador, no caso das religiões monoteístas, ou ao olimpo das divindades, quando se trata do politeísmo. Para a religião instituída, o sagrado concerne a uma natureza suprema e transcendental, região secreta a que excepcionalmente as pessoas têm acesso. Segue-se que o sagrado é a própria eternidade, em oposição à existência transitória das coisas e seres; é interdito às coletividades, mostrando-se apenas a indivíduos preparados, como sacerdotes e xamãs, e em ocasiões excepcionais, através de rituais preestabelecidos. O profano, por seu turno, é antítese do sagrado: espaço-tempo homogêneo do hábito, do consumo e das necessidades fisiológicas (comer, defecar, dormir, procriar etc.). Nessa acepção, o profano não passaria de uma emanação imperfeita e passageira da altíssima realidade (ELIADE, I992).

Há, entretanto, outra maneira de apreciar a questão. Em fins da década de I930, os franceses Roger Caillois, Michel Leiris e Georges Bataille fundaram o Collège de Sociologie, agremiação que passou a promover debates e conferências sobre temas importantes das ciências sociais ${ }^{2}$. Entre os assuntos discutidos, destacou-se o sagrado em sua interpenetração com o profano. Os debates visavam à compreensão da sociedade moderna a partir do que os intelectuais entendiam por "sociologia sagrada”, conceito que considerava o divino enquanto energia onipresente a permear todas as estruturas e relações sociais, determinando inclusive condições de poder, conhecimento, criação artística e ação política. Os organizadores do Collège de Sociologie buscaram ampliar uma tradição acadêmica consolidada no seio da École Pratique des Hautes Études, a qual colocava a religiosidade no cerne da teoria sociológica. Émile Durkheim, Marcel Mauss, Georges Dumézil e Mircea Eliade eram as principais referências dessa tradição, e serviram de base à dinâmica do Collège (GOYATÁ, 20I2).

Segundo Roger Caillois (I950), para o homem religioso, a existência se divide em dois planos complementares: um superficial, baixo ou profano, no qual é preciso

2 O Collège de Sociologie funcionou nos fundos de uma livraria, no número I5 da rua Gay Lussac, em Paris, de março de I937 a julho de I939 (GOYATÁ, 20I2). 
cumprir os afazeres cotidianos e agir conforme o hábito; outro essencial, alto ou sagrado, que interrompe do fluxo das ações costumeiras e faz nascer um sentimento de dependência e reverência em direção a uma força superior. Para o autor, ambos os planos se entrelaçam, visto que o sagrado é uma experiência intensa e extraordinária que se efetiva no mundo profano. Posta também em termos de puro e impuro, a relação seria de contato e mútua determinação, e não de distanciamento - profano seria o meio onde a vida se desenrola; sagrado, a fonte criadoura que vivifica e transforma todo viver (CAILLOIS, I950).

Grosso modo, a mesma perspectiva é partilhada por Michel Leiris (2003) e Georges Bataille (20I6). Para esses autores, o sagrado é imanência, intimidade entre Ser e mundo; é a temporalidade profunda do sentir, imensurável e incompreensível, que se desencadeia na experiência subjetiva (ou profana) - está, pois, presente em todos os acontecimentos vividos e coisas percebidas, antes que estes sofram a operação do intelecto ou da moral que separa sujeito e objeto. No sagrado, essas noções se fundem (BATAILLE, 20I6). Trata-se, então, de uma experiência intensa, sensível e direta (não reflexiva) do aqui-agora, pela qual o homem participa do supremo, sem se distinguir do mundo à sua volta. O sagrado é a potência infinita de que se alimenta o instante finito. Nesse sentido, mesmo o intercurso sexual, comumente visto como a mais baixa e profana das pulsões humanas, torna-se uma alavanca de ascensão espiritual (LEIRIS, 2003).

Não cabe aqui deslindar os meandros conceituais desse debate que fez escola no Ocidente. Para os propósitos do presente artigo, vale reter a relação de reciprocidade entre sagrado e profano que os autores acima comentados entreviam, conforme a qual qualquer evento ordinário pode ser experienciado enquanto manifestação do divino, ou seja, pode revelar a camada mais íntima e genuína da existência. Como veremos, nos poemas analisados, uma graça misteriosa vem impregnar imagens cotidianas, fazendo, de detalhes fortuitos e idiossincrasias eróticas, portas para as alturas celestiais3.

\section{VERSO HARMÔNICO}

No "Prefácio interessantíssimo", manifesto publicado em Pauliceia desvairada no ano de I922, Mário de Andrade defendia uma linguagem poética próxima da fala cotidiana. O escritor pensava em um lirismo autônomo - face à língua culta -, eivado de coloquialismos e insubmisso a determinações gramaticais rígidas (ANDRADE, 20I3)4. Para marcar posição, Mário teceu a noção de verso harmônico, que remetia ao vocabulário musicológico. À semelhança do acorde, o verso harmônico pressupunha a quebra da sequência gramatical discursiva, para que as palavras, "não sujeitas à

3 Rudolf Otto considera o sagrado como uma categoria apriorística, racional e não racional ao mesmo tempo. Nesse sentido, o sagrado, por ele chamado de "numinoso", é constitutivo da condição humana, e não uma substância transcendental (OTTO, I992).

4 O intelectual paulista pautou-se em autores vanguardistas como Émile Verhaeren, Jules Romains, Appolinaire, Jean Epstein, Paul Valéry, Jean Cocteau, Max Jacobs, André Breton e Paul Dermée (LOPEZ, I996). 
conexão linear, ressoem entre si, produzindo um efeito de superposição" (WISNIK, I983, p. II6). A analogia musical visava libertar a poesia da rigidez sintática imposta pelo padrão culto, potencializando a polissemia da linguagem. Assim, compondo campos harmônicos e polifônicos, as estrofes explodiriam em sensações e sentimentos vários, simultaneamente. A tese central partia do princípio de que simultaneidade, forma fragmentária, predominância de impactos sensoriais etc. eram características da vida moderna que deveriam pulsar no poema. Mário enxergava uma relação especular entre mundo e artefato literário, isto é, ele acreditava na possibilidade de ligação direta entre escrita e exterioridade. $O$ verso harmônico viria consolidar esse vínculo entre o real e o simbólico, ou o objetivo e o subjetivo (FRAGELLI, 20Io). O poeta, então, deveria abusar das frases telegráficas, da sobreposição de imagens, dos cortes bruscos, das aliterações, assonâncias e paronomásias, entre outros, porque, somente assim, a poesia poderia absorver em seu interior as experiências turbulentas e simultâneas que acometiam o indivíduo na sociedade industrial (ANDRADE, 20I3).

Em Pauliceia desvairada, as composições caleidoscópicas e ruidosas tencionavam retratar a São Paulo de começos da década de I920, a metrópole cosmopolita que se transformava velozmente, na balada da industrialização e dos fluxos de imigrantes, financiados pela economia cafeeira. Nesse momento, o autor abusou das ressonâncias e da livre associação de imagens. A ênfase na sonoridade e na visualidade previa incorporar as experiências diárias na textura poemática. As múltiplas figuras e os desvios abruptos da versificação corresponderiam a cenas da rotina metropolitana. Como se escrita e vida pudessem se fundir, na tessitura do poema, graças a remissões sonoras, estrepitosas, e a apelos visuais rebarbativos. Em mosaico, as composições de inícios dos anos I920 perseguiam o efeito de uma presença vigorosa, sem o qual a poesia não passaria de mero formalismo vazio (LAFETÁ, 2004).

\title{
Noturno do Cambuci
}

"Noturno", de Pauliceia desvairada, exemplifica o que acabamos de dizer. O poema é atravessado por imagens fragmentadas que se sobrepõem aleatoriamente, feito sonho. $\mathrm{O}$ eixo do poema são os bondes em seu movimento ao longo da noite, no bairro paulistano do Cambuci.

\author{
Noturno \\ Luzes do Cambuci pelas noites de crime... \\ Calor!... E as nuvens baixas muito grossas, \\ feitas de corpos de mariposas, \\ rumorejando na epiderme das árvores...
}

Gingam os bondes como um fogo de artifício, sapateando nos trilhos, cuspindo um orifício na treva cor de cal... 
Num perfume de heliotrópios e de poças

gira uma flor-do-mal... Veio do Turquestã;

e traz olheiras que escurecem almas...

Fundiu esterlinas entre as unhas roxas

nos oscilantes de Ribeirão Preto...

- Batat'assat'ô furnn!...

Luzes do Cambuci pelas noites de crime!...

Calor... E as nuvens baixas muito grossas,

feitas de corpos de mariposas,

rumorejando na epiderme das árvores...

[...].

(ANDRADE, 20I3, p. 96-97).

"Noturno" apresenta atmosfera misteriosa e algo sufocante. Sobre o breu denso e inescrutável, emergem linhas de luzes fugazes, que vêm e vão, acompanhadas de ruídos maquinares. A matéria de fundo é imóvel, enquanto as figuras de superfície são animadas pelo movimento vertiginoso dos bondes. A gravidade noturna pressiona e quase aniquila os contornos fluidos do que se pode divisar. O perfume dos heliotrópios corre o risco de se dissolver nas poças. As mariposas acabam se confundindo com a casca das árvores. "Noturno" mobiliza um jogo de contrastes. Então, o poeta se serve de um signo nuclear, que funciona como palavra mágica, a guardar todo o mistério da noite: "Batat'assat'ô furnn". A onomatopeia é o estrondo dos bondes; independe de gramática ou de etimologia; é inerente a um incidente externo, mas ao mesmo tempo ecoa no coração do poeta; é o verbo vivo em si, no qual se fundem a voz do eu lírico e o mundo que se lhe apresenta. $O$ bonde passa. "Batat'assat'ô furnn". Os versos vibram.

\section{[...]}

Um mulato cor de ouro, com uma cabeleira feita de alianças polidas...

Violão! “Quando eu morrer...” Um cheiro pesado de baunilhas

Oscila, tomba e rola no chão...

Ondula no ar a nostalgia das Baías...

E os bondes passam como um fogo de artifício, sapateando nos trilhos, ferindo um orifício na treva cor de cal...

- Batat'assat'ô furnn!...

Calor!... Os diabos andam no ar corpos de nuas carregando...

As lassitudes dos sempre imprevistos! 
e as almas acordando às mãos dos enlaçados!

Idílios sob os plátanos!...

E o ciúme universal às fanfarras gloriosas

de saias cor-de-rosa e gravatas cor-de-rosa!...

Balcões na cautela latejante, onde florem Iracemas

para os encontros dos guerreiros brancos... Brancos?

E que os cães latam nos jardins!

Ninguém, ninguém, ninguém se importa!

Todos embarcam na Alameda dos Beijos da Aventura!

Mas eu... Estas minhas grades em girândolas de jasmins, enquanto as travessas do Cambuci nos livres

da liberdade dos lábios entreabertos!...

[...]

(ANDRADE, 20I3, p. 97-98).

A livre associação de imagens, o sabor surrealista, os alaridos e a simultaneidade constroem o poema. A noite é sonho desperto em que vicejam "idílios sob os plátanos”. A cinestesia torna o perfume palpável e doura a música. Em meio ao colorido sensorial, sobressai o enlace amoroso em algum jardim verdejante. Talvez a flor-do-mal, vinda do Turquestã, fosse alguma prostituta que segredava esterlinas em suas unhas roxas. Os diabos, as mariposas e as flores têm um quê de metáforas libidinosas. As Baías ondulando no ar bem poderiam se passar pelas curvas do corpo feminino. E o que dizer das almas que só despertam “às mãos dos enlaçados”? Os "gravatas cor-de-rosa" e as "saias cor-de-rosa" fanfarronam em rituais cúpidos, perdidos nas alamedas do Cambuci.

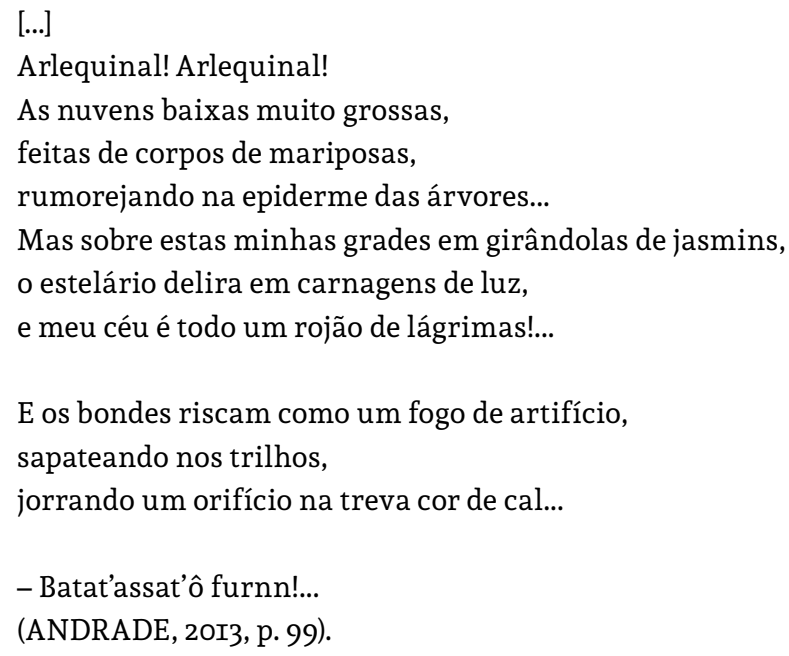

E os bondes riscam como um fogo de artifício, sapateando nos trilhos, jorrando um orifício na treva cor de cal...

- Batat'assat'ô furnn!...

(ANDRADE, 20I3, p. 99).

No final, o poema explode em êxtase, rojão de lágrimas se superpondo às estrelas. 
Não se contendo cá na terra, o poeta quer ascender, mergulhar no céu, feito fogo de artifício. As carnagens de luz revestem o poeta em seu orgasmo. O poema dá-se na tensão entre as condicionantes telúricas, pesadas, e a vontade de conquistar as alturas. A noite é trevosa, mas também ajardinada, paradisíaca. O paraíso, qual orifício luminoso, está contido na matéria escura. Os amantes só se amam porque a noite o permite, porque o intercurso se dá em um tempo que prescinde do trabalho e pode suspender a normalidade diuturna por alguns momentos. As trevas são a condição do enlevo, do relaxamento e da felicidade.

"Noturno" tensiona-se entre dois polos: a pulsão sexual e a necessidade de superá-la extaticamente. Essa tensão é acentuada pela pujança sonora e visual que caracteriza o poema. Dentre os sons, um em particular dita seu ritmo: "Batat'assat'ô furnn", palavra que visa reproduzir não somente o barulho dos bondes, mas também o roçar lascivo dos amantes, de modo simultâneo. Mais que isso. A onomatopeia funciona como estribilho e fecha o poema metaforizando o jorro extático do eu lírico. Trata-se de termo espectral, de significado indeterminado. "Batat'assat'ô furnn" é palavra mágica que desempenha o papel de mediadora entre o baixo e o alto, entre as paixões terrenas, efêmeras, e sua transcendência.

Segundo Marcel Mauss (2003, p. 99), "É a ideia mesma da magia a eficácia imediata e sem limites, a criação direta”. A instantânea realização do desejo é o corolário das fórmulas e ritos mágicos. Tal eficácia consiste em suprimir a distância entre linguagem e realidade, dizer e fazer, sujeito e objeto. Uma palavra encantatória tem a pretensão de fazer da própria enunciação um evento, retumbante e totalitário. Na magia, o vácuo entre significante e significado desaparece, e o Eu desejoso confunde-se com o objeto desejado, de modo que a palavra escapa do domínio da representação e adentra o âmbito ilimitado de um ato sublime, incognoscível'5. Daí as palavras mágicas serem ininteligíveis, ou mesmo impronunciáveis. Por elas, as discrições da fala comum e as diferenças entre idiomas são esfaceladas, e, da prosa ordinária, emerge o idioma adâmico, espelho cristalino do cosmos. "Batat'assat'ô furnn” é como o rastro dessa língua primeva, cuja sonoridade abstrusa incluiria o mistério de uma realidade superior. A expressão seria a senha mediante a qual se poderia penetrar o absoluto 6 .

Tal ruído exprime a elevação orgíaca do poeta, que, assim, percebe a luz em meio à escuridão. $O$ paradoxo reside no fato da palavra mágica advir do estampido de uma máquina comezinha, vulgar. "Batat'assat'ô furnn” é som ininteligível que faz a ponte entre o mundo dos homens e o indizível universo do além. No entanto, o encantamento, aqui, liga-se a uma ocorrência pedestre. Como poderia algo tão banal protagonizar uma composição que suscita a subida do poeta aos céus? Peça de ligação, a onomatopeia sinaliza que o alto já está inscrito no baixo, o todo no fragmentário, o eterno no momentâneo. O sagrado abrigar-se-ia em objetos e

5 Yves Vadé (I990, p. I6) fala em curto-circuito entre o desejo e o real.

6 Nessa chave, a onomatopeia aproxima-se da glossolalia e da pronúncia cabalística do nome oculto de Deus. Para Cláudio Willer (2010, p. 52-56), o desejo de um idioma original, linguagem anterior a toda linguagem, motivou grande parte dos poetas modernos, entre os quais, Léon-Paul Fargue, Artaud, Henri Michaux, Velimir Klébnikov, Hugo Ball e Vicente Huidobro. 
engrenagens quaisquer, e manifestar-se-ia por meio de barulhos e cintilações fugazes. O verbo divino seria implícito aos fenômenos temporais. Em "Noturno", a transcendência é imanente aos acontecimentos, sejam estes grandiloquentes ou fortuitos (como o simples estalido de um bonde). Podemos dizer que "Batat'assat'ô furnn” é o lugar mágico onde sagrado e profano, real e simbólico, infinito e finito, encontram-se inexoravelmente entrelaçados.

\section{Metáforas bíblicas}

Mário de Andrade apreciava a invenção de termos esquisitos. “Jorobabel” é o título de um poema que compõe o livro Losango cáqui7 e que, a exemplo de "Noturno", também problematiza a dicotomia entre o alto e o baixo. Também aqui temos uma palavra encantatória servindo de eixo a uma explosão imagética e sensorial. Contudo, ao invés de onomatopeia, "Jorobabel” é um neologismo. A disposição de seus versos segue itinerário inverso ao de "Noturno". Se nesse o ponto de partida são os trilhos dos bondes e as ruas da cidade, e o ponto de chegada é o êxtase celestial, "Jorobabel” segue a direção contrária: começa no céu e desce à terra, em lágrimas lamentosas.

\section{Jorobabel}

Um choro aberto sobre o universo desaba A badalar... Um choro aberto sobre a terra Em bando de ais... Guaiar profético se expande... Anda franco no mundo o agouro da miséria...

Job abúlico baba o fel que o devora... Hirta

A multidão que desapareceu Abel...

Um choro... E a vida excessivamente infinita!...

Clamor! Ninguém se entende! Um Deus não vem!... Babel!...

Babel! Um choro aberto sobre a confusão

Das raças! Babel! Os sinos em arremessos

Bélicos! Badalar dos sinos! Multidão

Hirta! Jerusalém incendiada... Rebate!

Babel! Jerusalém! Jorobabel! Babel!

Batem os bronzes bimbalhando! Pobre Job

Sem ouro, multidão devora e baba o fel...

Um choro aberto de entes misérrimos... Oh!...

(ANDRADE, 20I3, p. I75).

7 A maioria dos poemas de Losango cáqui foi escrita em I922, mas o livro só veio à tona em janeiro de I926 (ANDRADE, 20I3, p. I29). 
“Jorobabel” é um anagrama a rememorar personagens e parábolas bíblicas. Podem-se depreender desse neologismo os nomes Jó, Abel, Babel e Zorobabel. O poema ainda se reporta a Noé e Jerusalém (PAULA, 2002).

O choro sobre o universo, de que nos fala o verso inaugural, mimetiza o dilúvio bíblico. O livro do Gênesis assevera que, aborrecido pelos crimes e crueldades cometidos pelos homens, Deus decidiu mandar à Terra uma tempestade para que todo o planeta fosse inundado. Noé, por ordem divina, foi incumbido de construir uma enorme arca onde teve de acolher espécimes animais e os seres humanos de boa índole, escolhidos para sobreviver à catástrofe. "Um choro aberto" representa as lágrimas que Deus verteu pela tristeza com que ele via sua criação se desvirtuar. O dilúvio seria oportunidade para dar início a uma humanidade renovada, purificada do pecado. Ao iniciar seu poema com o choro de Deus, o eu lírico proclama sua vontade de renovação. $O$ poema começa apresentando as lágrimas purificadoras, vindas do alto, que retirariam do mundo as misérias e sofrimentos humanos (Bíblia de Jerusalém, 2002, Gn 6-9, p. 42-46).

Em seguida, temos a referência a Jó, também conhecido como Job. A Bíblia diz que Jó era um homem justo, pacífico e devotado a Deus. Pai de dez filhos, três moças e sete rapazes, Jó possuía muitas riquezas. Então, Deus perguntou a Satã o que ele achava da fé inabalável de Jó. Satã respondeu que Jó só era zeloso a Deus porque detinha grande fortuna e vivia confortavelmente. Se fosse um pária, Jó não seria capaz de ter fé e ainda amaldiçoaria Deus. Para provar que Satã estava errado e que sua criação lhe era fiel, Deus permitiu que o Tinhoso infligisse uma série de expiações contra Job: todos os seus filhos morreram, ele perdeu todas as suas posses e caiu gravemente enfermo. A princípio, Job não compreendeu como um homem tão dedicado a Deus poderia sofrer tamanho infortúnio. Fez menção de se revoltar, mas suportou com firme paciência as angústias, não renegando um só momento o nome da divindade. Ao final, vendo que Jó não desistia de louvá-lo, Deus não apenas lhe restituiu filhos e riqueza, como duplicou seus bens. Satã deu-se por vencido e reconheceu a sacralidade da criação (Bíblia de Jerusalém, 2002, Jó, p. 803-857).

A remissão a Jó e Noé denuncia o desejo, ao mesmo tempo, de resistência, resignação e transformação. Não obstante o tom amargo do poema, podemos flagrar nas entrelinhas a esperança de recomeço. "Jorobabel” mostra que, por detrás do mal e da injustiça, pode estar atuando uma modalidade de provação, ao cabo da qual o humano venha a se salvar. Apesar do fel que a multidão engole, e do dilúvio castigador, o poema insinua uma possibilidade de redenção.

Abel é outro símbolo bíblico no poema. Como se sabe, Abel era filho de Adão e Eva, irmão mais novo de Caim, por quem foi assassinado. De acordo com a fábula, Caim e Abel fizeram oferendas a Deus: o primeiro ofertou produtos agrícolas, o segundo, uma ovelha. Como Deus apreciou mais o regalo de Abel, Caim, sentindo ciúme, armou emboscada e matou o irmão. A parábola aborda o tema do fratricídio e da inveja; simboliza a exploração do homem pelo homem, a rixa e o ódio que separam as pessoas e as colocam frente a frente na arena das disputas e arrivismos sociais. No entanto, por trás da selvageria, há uma lei irrevogável. A multidão esqueceu o crime 
contra Abel, mas não é capaz de apagar o fato de que todos os seres humanos são irmãos, pois possuem a mesma origem divina (Bíblia de Jerusalém, 2002, Gn 4, p. 39-40).

A Torre de Babel também é ingrediente importante do poema. Segundo o livro do Gênesis, antigamente havia apenas uma comunidade humana sobre a Terra, unificada, que falava um idioma comum, a língua originária. Essa comunidade global decidiu construir uma torre que alcançasse o céu. Deus enfureceu-se com a ousadia humana e destruiu a edificação, dispersando os homens pelo mundo. A partir de então, a língua, que era unívoca, fragmentou-se em várias. Depois da queda, os idiomas se misturaram, e, no lugar da ordem e da paz, surgiu a confusão, a falta de comunicação e a violência (Bíblia de Jerusalém, 2002, Gn II, p. 48). No poema de Mário, a Torre de Babel metaforiza o contexto tumultuário de São Paulo no começo do século XX, provocado pelo crescimento econômico e industrial, pela ampliação das áreas suburbanas e pela metamorfose do centro com a construção dos grandes arranha-céus. O grande afluxo de imigrantes completa a imagem anárquica; era rotineiro ouvir uma pletora de idiomas se confundindo nas ruas paulistas durante as primeiras décadas da centúria (TOLEDO, 20I5).

As passagens bíblicas acima recenseadas indicam circunstâncias que resultam de ações irresponsáveis, excessivas. Por conta de sua desmesura, essas ações acabam sendo punidas, em observância à lei divina. É o que sugere o poeta ao citar Jerusalém. Mário de Andrade pinta São Paulo como o duplo da capital hebraica. Como se sabe, Jerusalém foi incendiada pelos babilônios, liderados por Nabucodonosor, na década de 580 a.C. ${ }^{8}$. Tal cataclismo foi interpretado como castigo divino perpetrado sobre o povo de Abraão, que vinha desobedecendo a Lei de Moisés e se distanciando da fé (Bíblia de Jerusalém, 2002, 2Rs 24-25, p. 543-545). Do mesmo modo, São Paulo estaria prestes a incendiar-se ou a afogar-se num mar de injúria, miséria, violência. Porém, a possibilidade de salvação é endossada pela alusão, implícita no título do poema, a Zorobabel. Esse personagem foi governador de Judá e responsável pela reconstrução do Templo de Jerusalém quando os israelitas retornaram do exílio na Babilônia, durante o século VI a.C. O Templo havia sido destruído por Nabucodonosor no contexto da invasão babilônica. Zorobabel é da linhagem do rei Davi, e seu nome significa o ungido, ou "filho do óleo", o que aponta sua proveniência sagrada. A perseverança em meio à adversidade, a coragem e a dedicação incondicional a Deus são símbolos que orbitam o nome de Zorobabel'. Seguindo a história de Jerusalém, a metrópole paulistana também guardaria uma natureza sagrada. Apesar de padecer dos excessos da modernização, no caos de São Paulo estaria inscrita uma potencialidade de redenção, posto que o desastre viria purgar os pecados humanos. Se Jerusalém mantivera-se sagrada, não obstante as inúmeras vicissitudes por que passara ao longo da história, São Paulo tampouco deixaria de ser a capital, sagrada, de um povo nascente.

Opera em “Jorobabel" uma retórica salvífica, em negativo, como pano de fundo do poema. Mário permite pensarmos a salvação não fora dos atos humanos, mas como

8 Calcula-se que a queda de Jerusalém tenha se dado em 587 a.C. (Bíblia de Jerusalém, 2002, p. 544, nota de rodapé h).

9 A história de Zorobabel pode ser conferida nos livros de Esdras, Ageu e Zacarias (Bíblia de Jerusalém, 2002, Esd 3-6, p.630-635; Ag I-2, p.I665-I667; Zc 4, p.I670-I67I). 
sucedâneo lógico desses mesmos atos, pois o castigo que recai sobre o agir pecaminoso também abriria a possibilidade de salvação. $\mathrm{O}$ mundo de agruras, resultante do erro e da desobediência, produziria as condições para o arrependimento, a redenção e a regeneração humanas - através, é claro, de um longo processo de aprendizado e paciência, consoante os episódios de Zorobabel e também de Job. O poema termina como começa: com o choro aberto, que é consequência do sofrimento, mas que é também princípio da salvação - o dilúvio reparador provocado pelas lágrimas de Deus.

“Jorobabel” se avizinha de "Noturno": em ambos o sagrado está contido no âmago de enredos profanos, ainda que em "Jorobabel" a experiência redentora consista na dor, enquanto, em "Noturno", baseia-se no prazer. Não seria forçoso afirmar que as metáforas bíblicas desempenham o mesmo papel que a onomatopeia “Batat'assat'ô furnn”: todas são signos ambivalentes que intentam conciliar dualidades, como sagrado e profano, redenção e perdição, permanência e efemeridade, espiritual e corporal etc. Ademais, à semelhança de "Noturno", "Jorobabel" também procura efetivar a tensão entre o alto e o baixo explorando a visualidade e a sonoridade, isto é, por meio de aliterações, frases telegráficas, quebra da sintaxe, livre associação de imagens etc.

\section{A DIVINA IMPUREZA}

No poema "XXXIII", de Losango cáqui, Mário cita em epígrafe uma passagem de Platão, e faz analogia, no corpo do poema, ao quadro A assunção da Virgem, do pintor espanhol Bartolomé Esteban Murillo ${ }^{\mathrm{T}}$. Vejamos como o poeta trabalha a associação entre o ícone cristão e o filósofo grego, e como essas balizas potencializam a relação entre o sagrado e o profano.

\section{XXXIII \\ "Prazeres e dores prendem a alma no corpo como com um prego. Tornam-na corporal... Consequentemente é impossível a ela chegar pura nos Infernos”.} Platão

Meu gozo profundo ante a manhã sol a vida carnaval... Amigos

Amores

Risadas

Os piás imigrantes me rodeiam pedindo retratinhos de artistas de cinema, [desses que vêm nos maços de cigarros.

Io Bartolomé Esteban Murillo nasceu em Sevilha, Espanha, a 3I de dezembro de I6I7, e faleceu na mesma cidade no dia 3 de abril de I682. Adepto do estilo barroco, a maioria de seus quadros aborda temática religiosa. A assunção da Virgem data de I670 e está entre as obras mais conhecidas do pintor (WIKIART, s. d.). 
Já estou livre da dor...

Mas todo vibro da alegria de viver.

Eis porque minha alma inda é impura.

(ANDRADE, 2013, p. 180-181).

O poema se inicia deleitoso e evoca o carnaval, a mais prestigiada festa profana. Nesse alvorecer, entre amores e risadas, uma cena trivial ganha contornos de arrebatamento, equiparando-se à assunção da Virgem, tal qual pintada por Murillo. No quadro (Figura I), a Virgem Maria ascende aos céus auxiliada por anjos; no poema, Mário está cercado de "piás imigrantes", que representam a mistura de culturas na cidade de São Paulo. Os meninos pedem maços de cigarros e fotografias de atores. Esses elementos mundanos contrastam com a pureza dos anjos e da Virgem, mas, ao mesmo tempo, tornam-se simétricos a eles. Com isso, o poeta sente-se a própria Assunção, mas cá embaixo, em meio às carnais afecções - e sem precisar aboli-las. A mensagem, então, fica clara: a vida, quando experimentada plenamente, intensamente, no cerne de suas contradições, já é, em si, sagrada. A felicidade dependeria não de evitar o mundo, como quer Platão, mas da entrega irrestrita aos sentimentos que o mundo suscita. Da mesma maneira, o impulso às alturas dependeria das vivências cotidianas. Se o preço para nos tornarmos puros é o cancelamento do prazer e da dor, melhor então que permaneçamos impuros. $\mathrm{O}$ poeta vibra de alegria porque, ironicamente, sua alma continua impura. 


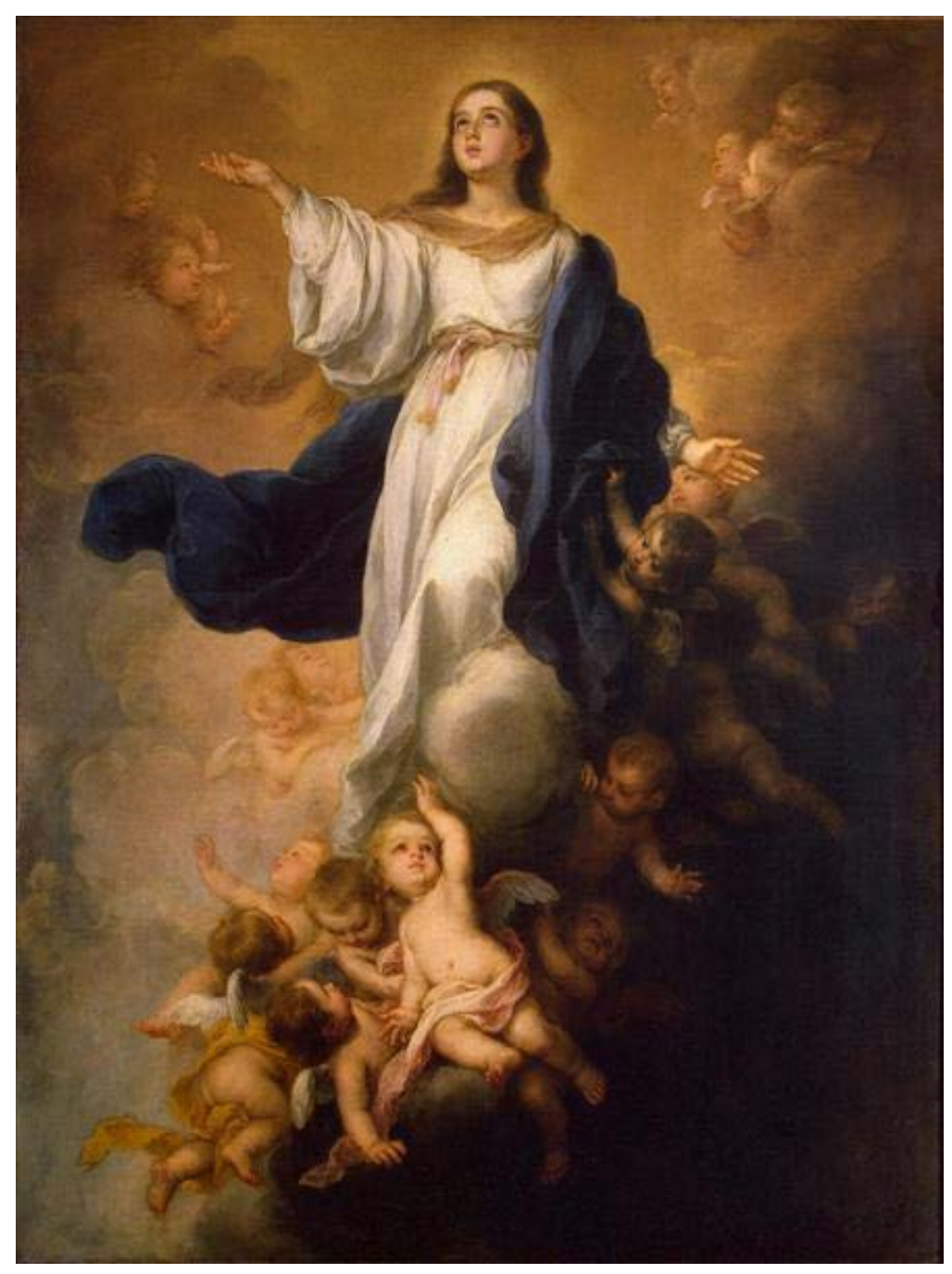

Figura I - A assunção da Virgem, de Bartolomé Esteban Murillo. Óleo sobre tela, I670. Fonte: WikiArt (s. d.)

Conforme depoimento do próprio Mário de Andrade, o poema acima é autobiográfico, inspirado nas manhãs em que o autor se encontrava no Quartel do bairro de Santana, quando cumpria o serviço militar, em agosto de I922. Dessa situação habitual, o poeta extrai um cenário de intensa emotividade. $O$ encanto e o júbilo seriam filhos da rotina. Para transmitir seus sentimentos, Mário sublinha o recurso do verso harmônico ao usar as palavras "amigos", "amores", "risadas" à maneira de um acorde:

E por associação de ideias, com 3 palavras soltas, resumi expressionistamente, por deformação sintética, o que faz a felicidade na minha vida: "amigos, amores, risadas". E coloquei estas palavras uma sob a outra, sem pontuação, porque devem agir como um 
acorde: não produzem sensações insuladas e seriadas, mas sensação complexa e total. E lá estão no Poema os impagáveis italianinhos que nos cercavam todas essas manhãs de exercício militar, quando saíamos do quartel de Sant’Anna. "Moço, me dá um artista!" A Assumpção de Murillo veio-me por associação de imagens. (ANDRADE, I922, p. 3).

O poema "XXXIII" possui continuação com a qual ele forma díptico: trata-se do soneto “XXXIII (bis) Platão", em que o eu lírico desdobra o paradoxo de ser impuro e divino simultaneamente. Mário chamará esse paradoxo de "A divina impureza", contrapondo-se à epígrafe de Platão. Mais uma vez, os versos buscam harmonizar o sagrado e o profano.

\section{XXXIII (bis) Platão}

Platão! por te seguir como eu quisera

Da alegria e da dor me libertando

Ser puro, igual aos deuses que a Quimera

Andou além da vida arquitetando!

Mas como não gozar alegre quando

Brilha esta alva manhã de primavera

- Mulher sensual que junto a mim passando

Meu desejo de gozo exaspera!

A vida é bela! Inúteis as teorias!

Mil vezes a nudeza em que resplendo

À clâmide da ciência, austera e calma!

E caminho entre aromas e harmonias

Amaldiçoando os sábios, bendizendo

A divina impureza de minha alma.

(ANDRADE, 20I3, p. I82).

O soneto destaca o rompimento do poeta com o idealismo platônico, e proclama a imersão nos aromas e harmonias da vida exuberante, diante da qual as teorias dos sábios e a ciência austera não passariam de inutilidades. A ode ao regozijo e à sensualidade, ainda que significasse decair no impuro, ratifica a crítica que Mário dirigia ao formalismo acadêmico- parnasiano ao reputá-lo demasiadamente abstrato e vazio, separado da realidade diária das pessoas. Cabia ao poeta antes cantar a manhã resplandecente do que se submeter a fórmulas teóricas sem conexão com o rotineiro. Destarte, à aliança entre sagrado e profano corresponderia o projeto marioandradino mais amplo de harmonização da poesia com a vida. A questão era efetivar uma linguagem viva, na qual a forma não estaria divorciada dos conteúdos experienciados pelo eu lírico - assim como o divino não estaria desatrelado do secular. A poesia não poderia se reduzir a um conjunto de regras, mas sim alimentar-se de fundos sentimentais, emotivos, afetivos etc., engendrados pela experiência ordinária. 


\section{O CARNAVAL CARIOCA}

A oralidade e o verso livre prevalecem em "Carnaval carioca”. Publicado no livro Clã do jabuti, em I927, o poema foi escrito em I923 e relata a experiência do autor no Rio de Janeiro, durante os festejos carnavalescos. O poema assemelha-se a um ritual de passagem: em meio à multidão delirante de mascarados, o eu lírico despoja-se de sua frieza de intelectual paulista, esquece os "preconceitos eruditos", e se desmantela em dança, liberando ondas de energia lírica. A ambiência abrasadora, fantástica e lúbrica faz lembrar “Noturno". Há cores, tatos e aromas em série. Porém, dessa vez não está em foco a capital paulista, senão que é o Brasil inteiro que se manifesta na grande festa popular ${ }^{\text {Ir }}$.

\section{Carnaval carioca}

a Manuel Bandeira

A fornalha estrala em mascarados cheiros silvos

Bulhas de cor bruta aos trambolhões,

Cetins sedas cassas fundidas no riso febril...

Brasil!

Rio de Janeiro!

Queimadas de verão!

E ao longe, do tição do Corcovado, a fumarada das nuvens pelo céu.

Carnaval...

Minha frieza de paulista,

Policiamentos interiores,

Temores da exceção...

E o excesso goitacá pardo selvagem!

Cafrarias desabaladas

Ruínas de linhas puras

Um negro dois brancos três mulatos, despudores...

$\mathrm{O}$ animal desembesta aos botes pinotes desengonços

No heroísmo do prazer sem máscaras supremo natural.

Tremi de frio nos meus preconceitos eruditos

Ante o sangue ardendo povo chiba frêmito e clangor.

Risadas e danças

Batuques maxixes

Jeitos de micos piciricas

Ditos pesados, graça popular...

Ris? Todos riem...

[...]

(ANDRADE, 2013, p. 210-211).

II Devido à extensão do poema, este artigo centra-se em alguns de seus trechos. 
"Carnaval carioca" traz para o centro da poética marioandradina a questão da identidade nacional (SOUZA, 2006). O escritor faz da própria vivência a oportunidade para traduzir sua visão de brasilidade - que surge aqui em sangue ardente, tonificada pelos ritmos mestiços do batuque "goitacá pardo selvagem". O povo brasileiro é esse carnaval: misturado, sensual, lúdico, mais afeito ao princípio do prazer e aos elãs corpóreos ("desengonços") do que à disciplina do trabalho e ao tempo do progresso. A a tensão entre sagrado e profano é aqui levada ao paroxismo: Mário vê a nação se sacralizar através da mais libertina das festas profanas. Seu carnaval é palavra mágica cujo encanto espraia-se coletivamente.



Constata-se no poema um erotismo altamente religioso, ou, por outro lado, uma religiosidade intensamente erótica. Os foliões são devotos que cumprem a promessa de gozar. A algazarra de imagens e sons sobrepostos realça o espetáculo em que se fundem brancos, negros e mulatos, e pelo qual se processa o enlevo coletivo. Em uníssono, e misturados, todos ascendem, mas o fazem nesse transe profano que é o carnaval. O infinito brota do ventre do finito; as banalidades alçam voo às alturas celestiais; puro e impuro tornam-se indiscerníveis. Os versos licenciosos desejam glorificar miragens efêmeras e, assim, tocar "realidades superiores". O canto do poeta, estimulado por impulsos baixos, pretende "acordar o segredo de seres e coisas" e capturar, no evento, a essência permanente do Ser. Feito fórmula mágica, esse canto quer penetrar o mistério divino, criar ambientes piedosos, tendo por alimento a ânsia humana dos sentidos. As eurritmias carnavalescas arrebatam - são percussões encantatórias, palavras mágicas encarnadas, pulsando na "Poesia imortal".

[...]

Ânsia heroica dos meus sentidos

Pra acordar o segredo de seres e coisas.

Eu colho nos dedos as rédeas que param o infrene das vidas, 
Sou o compasso que une todos os compassos,

E com a magia dos meus versos

Criando ambientes longínquos e piedosos

Transporto em realidades superiores

A mesquinhez da realidade.

Eu bailo em poemas, multicolorido!

Palhaço! Mago! Louco! Juiz! Criancinha!

Sou dançarino brasileiro!

Sou dançarino e danço! E nos meus passos conscientes

Glorifico a verdade das coisas existentes

Fixando os ecos e as miragens.

Sou um tupi tangendo um alaúde

E a trágica mixórdia dos fenômenos terrestres

Eu celestizo em eurritmias soberanas,

Ôh encantamento da Poesia imortal!...

[...]

(ANDRADE, 20I3, p. 2I4).

O poema é um grande rio efervescente. Sua disposição gráfica lembra o jorro de "Noturno", caudaloso e célere, no qual o poeta, não resistindo, se deixa levar. No caso de "Carnaval carioca", a catarse dilui as pessoas na multidão mestiçada. A nação aparece nesse fluir ritualístico em que europeu, tupiniquim e africano se cruzam, e onde o moderno alia-se ao primitivo (o tupi tange o alaúde). A civilização nascida dessa miscigenação possui algo de pecaminoso e redentor ao mesmo tempo: os excessos e a concupiscência do povo geram a condição de sua sublime identidade. $O$ regozijo eleva, enquanto o pecado prenuncia a salvação. Erotismo e religiosidade, elementos constitutivos do poema, também determinariam a singularidade brasileira. Em carta a Carlos Drummond de Andrade, de Io de novembro de I924, Mário confessava:

Eu conto no meu "Carnaval Carioca" um fato a que assisti em plena avenida Rio Branco. Uns negros dançando o samba. Mas havia uma negra moça que dançava melhor que os outros. Os jeitos eram os mesmos, mesma habilidade, mesma sensualidade mas ela era melhor. Só porque os outros faziam aquilo um pouco decorado, maquinizado, olhando o povo em volta deles, um automóvel que passava. Ela, não. Dançava com religião. Não olhava pra lado nenhum. Vivia a dança. E era sublime. (ANDRADE, 2002, p. 48-50).

O autor tinha em mente o seguinte trecho: "Só as ancas ventre dissolvendo-se em vaivéns de ondas em cio./ Termina se benzendo religiosa talqualmente num ritual” (ANDRADE, 20I3, p. 2I6). Mário parece fazer um paralelo entre o préstito carnavalesco e uma procissão. As referências ao imaginário religioso ocidental pontuam parte do poema. Há uma sequência consideravelmente extensa, por exemplo, em que o autor parodia os Salmos do Velho testamento, louvando-os como se participassem de um enorme conjunto de jazz-band. A louvação confunde-se com a festa profana; o bacanal da mestiçagem se desenrola nos moldes da liturgia cristã.

$[\ldots]$ 
Aleluia!

Louvemos o Criador com os sons dos saxofones arrastados,

Louvemo-Lo com os salpicos dos xilofones nítidos!

Louvemos o Senhor com os riscos dos recorrecos e os estouros do tam-tam,

Louvemo-Lo com a instrumentarada crespa do jazz-band!

Louvemo-Lo com os violões de cordas de tripa e as cordeonas imigrantes,

Louvemo-Lo com as flautas dos choros mulatos e os

[cavaquinhos das serestas ambulantes!

Louvemos $\mathrm{O}$ que permanece através das festanças virtuosas e dos gozos ilegítimos!

[...].

(ANDRADE, 2OI3, p. 2I9).

“Carnaval carioca” é uma erupção sensória. Para escrevê-lo, o autor não economizou ruídos, assonâncias, prosaísmos, imagens fragmentadas. A dinâmica caótica do texto procura assumir a forma paradoxalmente informe do evento. $\mathrm{O}$ poema é esparramado como as comoções de que se faz arauto. A abundância de figuras, adjetivos e frases aleatórias imprime-lhe intensidade e denuncia o propósito de tornar sua leitura tão marcante quanto a experiência originária. Acontecimento e representação, instante e eternidade, o baixo e o alto, enfim, vibrariam juntos em seus versos harmônicos.

\section{VIVER RELIGIOSAMENTE}

A dicotomia sagrado-profano, ou a tensão entre alto e baixo, atravessa boa parte da obra versificada de Mário de Andrade. Notam-se traços desse dualismo em poemas como "Rito do irmão pequeno", "Louvação da tarde" e "A meditação sobre o Tietê", para ficar nos mais conhecidos. Nos poemas analisados neste artigo, o ser humano encontraria o sagrado nos imbróglios e afecções terrenas. A redenção estaria no viver intenso, tanto na dor quanto na alegria. Em todas essas composições foi experimentado o verso harmônico, mediante o qual o escritor queria salientar a dimensão sensória, paradoxal e simultânea da linguagem. As figuras e ressonâncias empregadas nos poemas visam ao efeito de simultaneidade ou harmonia dos opostos.

Na poesia de Mário de Andrade, o sagrado concerne a um universo superior e extemporâneo, mas, paradoxalmente, também se faz presente nas paixões terrenas. Assim, temos um jogo de dualidades que não se resolve, senão que se mantém em perpétuo movimento: o indizível está no dito, da mesma maneira que o divino está no humano - ou o atemporal, no instante vivido. A lírica modernista, como queria Mário, surgiria de um transe mediúnico, alcançado pela experiência de dor ou de prazer (FRAGELLI, 20Io). Esse transe corresponderia ao que o autor entendia por religiosidade. Nessa perspectiva, poetar significaria exultar, isto é, sentir a vida religiosamente. Vejamos como Mário trabalha esse aspecto no poema “Religião”, de Pauliceia desvairada. 


\section{Religião}

Deus! creio em Ti! Creio na tua Bíblia!

Não que a explicasse eu mesmo,

porque a recebi das mãos dos que viveram as iluminações!

Catolicismo! Sem pinturas de Calixto!... As humildades!...

No poço das minhas erronias

vi que reluzia a lua dos teus perdoares!...

Rio-me dos Luteros parasitais

e dos orgulhos soezes que não sabem ser orgulhosos da verdade;

e os mações, que são pecados vivos,

e que nem sabem ser Pecado!

Oh! minhas culpas e meus tresvarios!

E as nobilitações dos meus arrependimentos

Chovendo para a fecundação das Palestinas!

Confessar!...

Noturno em sangue do Jardim das Oliveiras!...

Naves de Santa Efigênia,

os meus joelhos criaram escudos de defesa contra vós!

Cantai como me arrastei por vós!

Dizei como me debrucei sobre vós!

Mas dos longínquos veio o Redentor!

e no poço sem fundo das minhas erronias

vi que reluzia a lua dos seus perdoares!...

"Santa Maria, mãe de Deus..."

A minha mãe-da-terra é toda os meus entusiasmos:

dar-lhe-ia os meus dinheiros e minhas mãos também!

Santa Maria dos olhos verdes, verdes,

Venho depositar aos vossos pés verdes

a coroa de luz da minha loucura!

Alcançai para mim

a Hospedaria dos Jamais Iluminados!

(ANDRADE, 20I3, p. IO7-IO8).

Como em "Jorobabel", o eu lírico lamenta a culpa pelos atos inconsequentes, mas recorda que essa culpa antecede o arrependimento por meio do qual o pecado é redimido. Espelhando a alegoria de Noé, o choro sofrido, fruto da desmesura, 
contribui para a redenção, e, "chovendo para a fecundação de Palestinas", preludia o início de uma nova Era. O sintagma "no poço das minhas erronias/vi que reluzia a lua dos teus perdoares!...” alude ao episódio neotestamentário da mulher samaritana. O evangelho de João conta que Jesus encontrou-se com a samaritana no poço de Jacó quando passava pela região da Samaria. Jesus parou no local para repousar e pediu um pouco d'água para a mulher, que ficou surpresa, pois os judeus não se davam bem com os samaritanos. O pedido foi um teste, e em seguida, após revelar alguns fatos da vida íntima da samaritana, Jesus provou-lhe que era o Messias. A parábola simboliza o perdão, o amor e a confraternização (Bíblia de Jerusalém, 2002, Jo 4, p. I850-I852). No poema, o poço é metáfora dos pecados que se acumulam nas profundezas da alma, mas sobre os quais resplandece a luz curativa que vem do alto. Não importa o quanto nos distanciamos do céu: dos longínquos virá o Redentor.

O Jardim das Oliveiras é outra imagem bíblica utilizada no poema. À maneira de "Noturno", em "Religião" também figura a noite misteriosa. Desta vez o poeta refere-se à noite que Jesus passou no Getsêmani, ou Jardim das Oliveiras, orando com os apóstolos às vésperas da crucificação. $\mathrm{O}$ evangelho de Lucas relata que a angústia de Jesus foi tanta que ele transpirou sangue, e seu suor escorreu pelo solo (Bíblia de Jerusalém, 2002, Lc 22, 39-46, p. I829). Não obstante a comoção da passagem, ao reportá-la, o poeta suscita um sentimento de esperança, haja vista que Cristo foi sacrificado para nos salvar. Portanto, o sangue vertido no Jardim das Oliveiras pode ser visto como o anúncio do tempo messiânico, que virá redimir a humanidade.

O poema termina de modo paradoxal. O eu lírico roga a Santa Maria a "Hospedaria dos Jamais Iluminados”, sugerindo que ele mesmo jamais alcançaria a iluminação. Na melhor das hipóteses, depositaria sob os pés da santa a coroa de luz de sua loucura. O paralelo com a coroa de espinhos é evidente. Queria Mário colocar-se como um santo às avessas, cuja santidade habitaria a loucura e o pecado? O paradoxo com que o poema é finalizado lembra o díptico "XXXIII", quando o poeta proclama a divina impureza de sua alma. Para o autor da Pauliceia, fé e lirismo caminhavam juntos. Que o testemunhe a igreja de Santa Efigênia. Em certa medida, a loucura iluminada replica a divina impureza: é outra maneira de dizer que sagrado e profano talvez fizessem parte do mesmo Ser.

Na carta a Carlos Drummond, já mencionada, de novembro de I924, Mário de Andrade convocava o literato mineiro a viver religiosamente, o que significava: deixar de ser um "intelectual de gabinete", ir às ruas e conversar com o povo, preterir a erudição livresca em benefício dos contatos intersubjetivos, in loco. Gostar da vida seria vivê-la com religião, mas a religião nesse caso ganha um teor profano. Paradoxalmente, o gozo do que é baixo enlevaria o poeta. Eis a missiva:

Tudo está em gostar da vida e saber vivê-la. Só há um jeito feliz de viver a vida: é ter espírito religioso. Explico melhor: não se trata de ter espírito católico ou budista, trata-se de ter espírito religioso pra com a vida, isto é, viver com religião a vida. Eu sempre gostei muito de viver, de maneira que nenhuma manifestação da vida me é indiferente. [...]. E então parar e puxar conversa com gente chamada baixa e ignorante! Como é gostoso! Fique sabendo duma coisa, se não sabe ainda: é com essa gente que se aprende a sentir e não com a inteligência e a erudição livresca. Eles é que conservam 
o espírito religioso da vida e fazem tudo sublimemente num ritual esclarecido de religião. (ANDRADE, 2002, p. 46-48).

O poema e a epístola citados acima ressaltam a aura ecumênica que Mário enxergava nas vivências cotidianas. A gente "chamada" baixa e a "hospedaria dos jamais iluminados" abrigariam o rico manancial de sentimentos que Mário buscava para alimentar sua obra. Nessa baixeza comunitária estaria a chave para a dignidade da poesia moderna. Pois o sublime não estaria desconectado das relações mundanas, mas seria constitutivo dessas mesmas relações. Nota-se que o autor propugnava ligar o alto e o baixo de tal forma que ambos se convertessem um no outro sem cessar. E o responsável por essa ligação seria o expediente mágico/religioso. A transição de uma instância a outra, entretanto, não se daria através de um processo dialético e linear, num plano sucessivo em que uma tese, contraposta a sua antítese, desembocaria em síntese; antes, essa transição se daria num plano vertical e/ou circular, em que os termos coexistissem e se tornassem intercambiáveis.

Em Mário de Andrade, a religião conectaria o alto e o baixo à medida que intensificasse estados anímicos no aqui-agora da experiência - quando o poeta escolhesse imergir na vida comunal. Ou seja, a vida experienciada com religião reverberaria o que Mário entendia por lirismo e verso harmônico. A religiosidade consistiria em viver o presente em toda a sua plenitude e complexidade, como um acorde musical. Para o autor, o viver se entrelaçaria ao fazer poético (e à atividade artística de modo geral) se o poeta sentisse intensamente, religiosamente, aquilo que a vida lhe oferecesse. Essa intensa entrega participa da proposta estética marioandradina conforme a qual a distância entre palavra e realidade deveria se dissolver na confecção literária. A atividade de escrever deveria estar de tal maneira amalgamada à experiência social que ambas entrariam em uma zona de indiferenciação. A harmonia dos contrários residiria, justamente, nessa concomitância entre existir e ser, transitoriedade e permanência, efetivada na suposta abertura que o poeta vislumbrava entre a escrita e o mundo.

\section{SOBRE O AUTOR}

CAION MENEGUELLO NATAL é pós-doutorando no Instituto de Estudos Brasileiros da Universidade de São Paulo (IEB/USP).

E-mail: caionnatal@hotmail.com

https://orcid.org/oooo-0003-0357-3202 


\section{REFERÊNCIAS}

ANDRADE, Carlos Drummond de. Carlos e Mário: correspondência entre Carlos Drummond de Andrade e Mário de Andrade: I924-I925. Org. Lélia Coelho Frota. Rio de Janeiro: Bem-Te-Vi Produções Literárias, 2002.

ANDRADE, Mário de. Farauto. Klaxon - mensário de Arte Moderna de São Paulo, São Paulo, n. 7, novembro de I922.

. Poesias completas - Volume I. Ed. Tatiana Longo Figueiredo e Telê Ancona Lopez. Rio de Janeiro: Nova Fronteira, 20I3.

BATAILLE, Georges. Teoria da religião: seguida de Esquema de uma história das religiões. Belo Horizonte: Autêntica, 2016.

BÍBLIA de Jerusalém. São Paulo: Paulus, 2002.

CAILLOIS, Roger. L'homme et le sacré. Paris: Gallimard, I950.

ELIADE, Mircea. O sagrado e o profano. São Paulo: Martins Fontes, I992.

FRAGELLI, Pedro Coelho. A Paixão segundo Mário de Andrade. Tese (Doutorado em Letras). Departamento de Letras Clássicas e Vernáculas, Faculdade de Filosofia, Letras e Ciências Humanas, Universidade de São Paulo, 2010.

GOYATÁ, Júlia Vilaça. Georges Bataille e Michel Leiris: a experiência do sagrado (I930-I940). Dissertação (Mestrado em Antropologia Social). Departamento de Antropologia, Faculdade de Filosofia, Letras e Ciências Humanas, Universidade de São Paulo, 2012.

LAFETÁ, João Luiz. A poesia de Mário de Andrade. In: . A dimensão da noite e outros ensaios. São Paulo: Duas Cidades; Ed. 34, 2004.

LEIRIS, Michel. A idade viril. São Paulo: Cosac Naify, 2003.

LOPEZ, Telê Ancona. Arlequim e modernidade. In: . Mariodeandradiando. São Paulo: Hucitec, I996.

MAUSS, Marcel. Esboço de uma teoria geral da magia. In: . Sociologia e antropologia. São Paulo: Cosac Naify, 2003.

OTTO, Rudolf. O sagrado. Lisboa: Edições 70, I992.

PAULA, Adna Candido de. A Jorobabel Marioandradina: poesia e crença. Dissertação (Mestrado em Letras). Instituto de Estudos da Linguagem, Universidade Estadual de Campinas, 2002.

SOUZA, Cristiane Rodrigues de. Clã do Jabuti: uma partitura de palavras. São Paulo: Annablume, 2006. TOLEDO, Roberto Pompeu de. A capital da vertigem: uma história de São Paulo de I900 a I954. São Paulo: Objetiva, 20I5.

VADÉ, Yves. L'enchantement littéraire: écriture et magie de Chateubriand à Rimbaud. Paris: Gallimard, I990. WIKIART - Visual Art Encyclopedia. Bartolome Esteban Murillo. Disponível em: <https://www.wikiart. org/en/bartolome-esteban-murillo >. Acesso em: Io jun. 20I8a.

WIKIART - Visual Art Encyclopedia. The Assumption of the Virgin. Bartolome Esteban Murillo. Disponível em: 〈https://www.wikiart.org/en/bartolome-esteban-murillo/the-assumption-of-the-virgin-I670〉. Acesso em: Io jun. 20I8b.

WILLER, Cláudio. Um obscuro encanto: gnose, gnosticismo e poesia. Rio de Janeiro: Civilização Brasileira, 2010.

WISNIK, José Miguel. O coro dos contrários: a música em torno da semana de 22. São Paulo: Livraria Duas Cidades, I983. 